
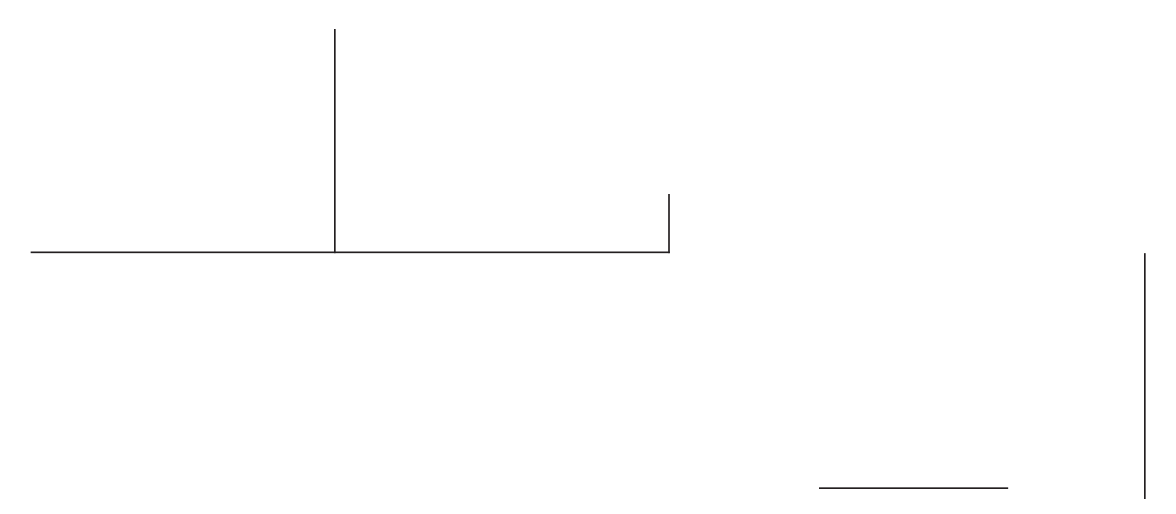

\title{
A casa-ambiente. Anotações sobre arquitetura e psicanálise de Winnicott
}

\author{
Esther Cervini
}

Pretendo estabelecer uma aproximação entre a psicanálise de Winnicott e arquitetura, a partir da relação entre o ambiente e a casa, isto porque a abordagem winnicottiana do conceito de objetosubjetivo permite pensar um estágio de fusão entre mãe-bebê que vai encontrar um paralelo entre indivíduo-casa e indivíduo-cidade em sua fase adulta. $O$ ser humano não pode existir sem um habitat, como aponta Winnicott, e as psicopatologias profundas, caracterizadas pelas angústias impensadas, seriam decorrentes de falhas no processo de instalação do indivíduo no mundo. Portanto, em que medida a arquitetura pode afetar o existir humano, uma vez que é a única das artes realmente capaz de abrigar, ou seja, capaz de constituir-se concretamente num ambiente pela sua capacidade essencial de envolvimento, antes mesmo que seja tomada como objeto de representações e desejos? 


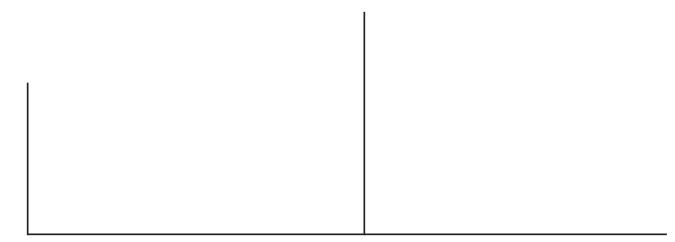

\section{Introdução}

Antecipadamente ao tema que desejo tratar neste texto - anotações acerca da relação entre o indivíduo, a casa e a cidade -, gostaria de dizer um pouco do percurso que levou uma arquiteta a se interessar por psicanálise, sobretudo pela escolha da psicanálise de Winnicott. Digo, verdadeiramente, que não foi uma escolha, mas um encontro, porque as minhas indagações em arquitetura sempre rondaram as noções de espaço e lugar, e, de certa forma, Winnicott aponta uma compreensão da constituição da psique humana inseparável da provisão ambiental. Cada indivíduo criaria as suas formas próprias de espacializar e temporizar desde o evento originário de ser lançado no mundo, e estas formas, segundo Winnicott, transformam-se, acompanhando um processo individual de desenvolvimento emocional.

A arquitetura possui uma particularidade em relação às outras artes, particularidade esta que até colocaria em jogo a esteticidade da arquitetura. Ela permite um envolvimento, algo que escapa a qualquer tentativa de explicação, visualização ou experimentação sensorial. Isto quer dizer que a comunicação entre obra e visitante se faz sem intermediários, porque permite ao indivíduo o pertencimento a um lugar que se inaugura com a obra. A arquitetura tem a capacidade peculiar de fazer pensar em algo totalmente diverso dela própria, "aqui" e "lá" ao mesmo tempo. De conduzir, aproximando e afastando, para outros mundos que evocam criações de universos.

Do ponto de vista de um arquiteto, Winnicott vai propor uma psicanálise a partir da necessidade de instalação como condição de existência no mundo. Detenho-me em integração espacial que é um tema-chave para começar a traçar aproximações entre arquitetura e psicanálise. As psicopatologias, portanto, decorreriam de alguma falha ambiental nesse processo de instalação no mundo. Pode-se dizer que esta falha, revelada por uma angústia profunda, é sentida como desinstalação e ausência da existência de um meio, como abismo que se abre entre ser e deixar de ser.

Do ponto de vista da psicanálise, a arquitetura pode oferecer-se como mundo que dê lugar a outros mundos, fazendo-nos pertencer, 
concretamente, às realidades subjetivas vividas pelos pacientes cujas patologias, em especial as psicoses, se caracterizem pela ausência de limites entre o real e o irreal, por meio do estudo das espacialidades complexas que cada caso apresenta como formas, criativas ou precárias, de construção de morada sobre a falha ambiental.

Um fragmento de caso apresentado por Winnicott em Holding $e$ interpretação ilustra o modo como aparecem traços da vertente do processo espacial do processo de integração ambiental numa situação analítica: “... ele, deitado no divã num estado momentâneo de retraimento, encolheu-se e rolou por cima da cabeceira do divã". Adiante, Winnicott acrescenta: "Ao falar de si mesmo como estando encolhido e se movimentando, você está ao mesmo tempo sugerindo a existência de algo que naturalmente lhe escapa à consciência; você está sugerindo a existência de um meio". Menos que perguntar a respeito do lugar que o paciente está ocupando numa estrutura de parentescos, interessa-me a possibilidade do lugar (o setting psicanalítico) revelar estados psíquicos quando o paciente revela espaços e tempos outros, num divã, que é um ambiente confiável. Winnicott fala da possibilidade desses estados de retraimento serem convertidos em regressão, tornando o paciente capaz de usar esta experiência de maneira edificante.

Em particular, minha intenção será, numa escala equivalente ao que o divã é para o analista, a de indicar um possível caminho, através da leitura arquitetônica dos espaços que habitamos, nossas casas e nossas cidades: a contínua oscilação entre pertença a um lugar e desenraizamento constrói uma ponte sobre o abismo, a forma arquitetônica mais próxima daquilo que eu poderia chamar de morada no mundo contemporâneo.

Indistinção entre realidade e irrealidade ou realidade e virtualidade, seja em relação à crise da representação na arquitetura e nas artes em geral (fenômeno artístico chamado de homeless representation), seja no que se refere à crise das relações objetais como fundamento da psicanálise tradicional, encontrada nas obras de Winnicott à Fédida - eis um paralelo a ser anotado.

\section{Casa: um motivo}

A casa consiste num motivo que interessa tanto à psicanálise quanto à arquitetura. No entanto, não se encontra freqüentemente discutido por qualquer dos campos. Em arquitetura, faz-se pouca referência à casa nos tratados teóricos, mesmo porque o hábito de um arquiteto projetar residências individuais é muito recente na história da arquitetura e à exceção de edifícios habitacionais coletivos, que surgiram há menos de dois séculos, os arquitetos têm se dedicado à obras de arquitetura genial ou monumental que se colocam, na maioria das vezes, fora 


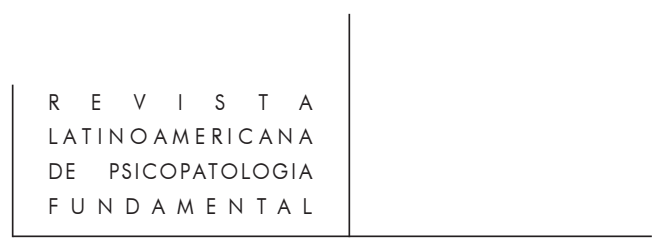

da situação espaço-temporal. Na psicanálise tradicional, embora se encontre algumas passagens sobre o motivo da casa em Jung (que pôde anotar sobre sua experiência pessoal na construção da própria casa durante 30 anos), são ainda mais raros os relatos de casos cujo objeto de discussão seja a casa. Talvez porque a casa não seja um simples objeto, e aqui arrisco-me ao dizê-lo.

Se entendo a casa pelo que nela há de arquitetônico em sua arquitetura, as estruturas e os sistemas teóricos que a formalizam, a construçã, estará acabada muito antes de que seja realmente edificada, porque encerra, desde o seu projeto, uma concepção dada de mundo. E a esta construção nem poderíamos chamar de casa, uma vez que condicionada a alguma finalidade ou função específica inalterável, não abrigará seus ocupantes à medida que estes mudem de necessidades. Estou referindo-me a desejos ou realização de sonhos dos ocupantes quando falo em necessidades. ${ }^{1}$ Por um lado, temos a obra tratada como objeto de representações pelo cliente, e isto o leva à construção de uma idéia de casa, e não da casa, materializada unicamente para torná-la espelho da imagem que se tem como casa. Por outro, temos o espaço desta arquitetura como representação de uma "visão de mundo", que muitos arquitetos tentam praticar, financiado pelo cliente. De qualquer modo, a estruturação da forma arquitetônica do espaço seria o equivalente da estrutura (o arquitetônico) das relações que formam um conceito. Espaço é visto como produto do conhecimento humano, é coisa mental. Dizemos, portanto, que um conceito é arquitetônico.

Mas não é desta arquitetura que quero tratar.

A relação entre dois conceitos parece-me fundamental para discutir a

1. Estes fragmentos de entrevistas de dois arquitetos brasileiros para a revista Arquitetura e construção, dão a dimensão da relação cotidiana entre cliente e arquiteto. Éolo Maia: "A relação entre cliente e arquiteto deve ser de confiança total. A única pessoa que pode julgar o arquiteto é o cliente. Nós devemos interpretar o sonho dele e transformá-lo em realidade. Preciso ser honesto comigo e com meu cliente ao fazer o projeto de uma casa. Essa etapa é muito importante, mas também acho essencial que o arquiteto participe da obra, dê assistência durante a construção." José Eduardo Tibiriçá: “Acho que o principal é traduzir no projeto o que o cliente deseja, e na maioria das vezes não sabe o que quer. Por isso, é importante conhecer a maneira como esse cliente vive e como vai viver dali para a frente. Muitas vezes, as pessoas vem com uma fórmula, querendo uma casa mediterrânea, americana ou tipo villaggio italiano. Nessa hora, o arquiteto tem que interpretar esse desejo, ou seja, não necessariamente fazer igual, mas na verdade entender que é esse o clima que a pessoa procura. E, com esse dado e com outros que o cliente passar, desenhar soluções." É possível perceber que o primeiro elemento observado por ambos os arquitetos relaciona-se aos desejos, projeções e fantasias depositadas na casa enquanto objeto de representações. Em termos psicanalíticos, estaríamos dentro de um universo conceitual freudiano. Mas tanto a referência à confiança e à assistência durante a construção da casa real, quanto à tarefa do arquiteto em fazer o cliente encontrar o clima (ambiente) e modo de vida que o acolha, parece-me indicar um caminho possível para relacionar a arquitetura e a construção da casa com a abordagem psicanalítica indicada por Winnicott. 
questão da casa dentro da arquitetura, a saber, a relação entre lugar e espaço. Sobre a noção de lugar tratarei mais adiante.

Quando digo que a arquitetura tradicional está comprometida com o arquitetônico da arquitetura, refiro-me à idéia moderna de que espaço é uma representação a priori, ao modo como Kant o enunciou em Crítica da razão pura, ou seja, que "espaço é uma condição de possibilidade dos fenômenos", portanto, espaço não seria uma atribuição exclusiva da arquitetura. Se o espaço é dado, então não é manipulável, produzível ou organizável. O que se manipula, se produz e se organiza são os objetos no espaço. Daí a dificuldade de se definir espaço.

Por outro lado, se faz necessário dizer que a "história da arquitetura é, antes de tudo e principalmente, a história das concepções espaciais" (Bruno Zevi, 1973), portanto, se falamos de espaço não podemos nos referir a uma realidade objetiva, mas espaço como algo que tem um desenvolvimento histórico (Argan, 1966). E se verificamos que os espaços se transformam continuamente em arquitetura, este fato deve-se a um movimento próprio da existência da humanidade. Um conceito de espaço vai dando lugar a outro conceito de espaço.

Então, espaço pode significar, também, lugar. E estaria aproximando a noção de espaço ao seu sentido originário grego chora, que não quer dizer espaço como conceito moderno metafísico. Neste sentido, "em arquitetura, forma espacial significa lugar, percurso, área, ou seja, a estrutura concreta do ambiente humano" (Norberg-Schulz, 1975) ${ }^{2}$.

Uma vez perguntaram a um dos maiores arquitetos modernos, Mies van der Rohe, porque ele vivia num pequeno apartamento de um velho edifício, sendo ele o autor das maiores torres de ferro e vidro em Chicago, nos anos 30, ao que ele respondeu: "Morar se mora em qualquer lugar, e arquitetura é a construção de uma idéia". Sua arquitetura é a pura construção do espaço, como algo infinito, a tábula rasa, e o edifício um pequeno detalhe de infinito, porque sendo todo de vidro, ele não se impõe como objeto aparente, não se vê seus limites, assim como é possível se olhar através dele. As pessoas parecem flutuar no espaço por ele criado. Mas se é possível construir uma idéia, será possível habitá-la? As casas de vidro de Mies também desabrigam e a fluidez de seus espaços me faz refletir sobre a situação do homem que não mais poderia encontrar um lugar na cidade moderna. Isto quer dizer que até a mais elaborada arquitetura conceitual revela um tipo de experiência de abrigo: o desabrigo e a tentativa desesperada de construir intelectualmente algum tipo de casa.

O que é isso a que chamamos casa?

É muito difícil para um arquiteto admitir que uma casa pode ser edificada por qualquer pessoa. A própria cidade é prova desse fato. Isso me permite pensar

2. Norberg-Schulz. Existencia, espacio y arquitectura. Barcelona, Blume, 1975. 


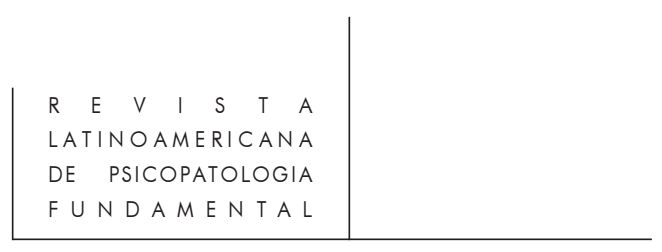

em uma arquitetura na qual inexiste uma forma prévia do que a casa pode ser. Refletir sobre a essência da casa, naquilo que ela é em sua origem, pode ampliar os horizontes do que se tem considerado como arquitetura. Basta-me, por enquanto, dizer, que a casa é onde vivemos. Onde somos o que somos. Este onde pode ser entendido tanto como lugar quanto por espaço ou, ainda, pela época em que vivemos.

A casa, como motivo, é algo que se repete, mas diferencia-se em cada repetição. A casa que abriga um indivíduo na infância não terá a mesma configuração, não será mais a mesma, de quando ele for adulto, embora a experiência de estar abrigado tenha sua origem nos seus primeiros momentos no mundo. $\mathrm{O}$ que quero chamar de casa é o que identifica os modos como se vive e onde. Para viver, o ser humano precisa de uma habitação. Ao longo da vida ele constrói um sentido de si mesmo, ao mesmo tempo em que habita no mundo. A isto Winnicott chama de teoria do desenvolvimento emocional. Quando o processo de integração de si mesmo se completa, ou seja, quando o indivíduo já se integrou no tempo, depois no espaço, construiu uma imagem para seu corpo e consegue lidar com os objetos distanciados de si, então o indivíduo pode se dar ao luxo, até, de deixar de ser o que se é, mudar o seu modo de ser ou preparar-se para desabitar o mundo, iniciando-se ao poder-morrer no sentido heideggeriano. Winnicott fala que à medida que um ser humano amadurece, o meio ambiente cada vez mais se torna um fenômeno separado do si mesmo, ficando relegado a segundo plano ${ }^{3}$.

Enquanto na psicanálise tradicional da psiconeurose o conflito se revela dentro do indivíduo, no inconsciente reprimido, portanto a análise se conduz baseada no complexo de Édipo, Winnicott vai dizer que nos casos psicóticos, a base do conflito desloca-se para o que ele chama de cisão básica na pessoa do paciente, havendo um extremo de dissociação. É importante ressaltar que se esta cisão ocorre - e na psicanálise de Winnicott toma o lugar do inconsciente reprimido do neurótico - é porque a dissociação constitui-se num estado anterior à formação de um si mesmo integral (dissociação = não-integração, que difere de desintegração), muito distinto, portanto, do tratamento dado por Freud às psicoses relacionando-as à cisão do ego que já estaria pressuposto como existente.

3. D.W. Winnicott. "O conceito de regressão clínica comparado com o de organização defensiva", in Explorações psicanalíticas, Porto Alegre, Artes Médicas, 1993, p. 152. "À medida que a criança adquire autonomia e uma identidade, que se sente real e percebe objetivamente o meio ambiente como fenômeno separado, assim também o meio ambiente torna (na saúde) cada vez mais relegado ao segundo plano, exceto na doença - tal como na esquizofrenia - tem-se sempre de lembrar que o meio ambiente pode ser um fator adverso, por causa do fracasso do indivíduo em obter suficiente autonomia." 
O problema da habitação ou instalação no mundo constitui-se num problema de existência. Winnicott não destrói a psicanálise tradicional. Ele a desconstrói, porque muda as bases filosóficas que estão fundamentando a psicanálise tradicional. E a relevância dos seus estudos psicanalíticos está em mostrar-nos que o existir humano depende de um ambiente facilitador, aceitando, no entanto, um paradoxo, o de que não é o ambiente que cria o ser humano. O indivíduo cria-se a si mesmo, mas só pode criar-se a si mesmo se houver, inicialmente, a mãe-ambiente que empresta ao bebê não seu ego, mas sua tendência à unidade ou integração.

A única tendência nata do indivíduo é a de integração (tendência à existência), e o processo de amadurecimento pessoal, sobre o qual Winnicott sedimenta seus demais conceitos, consiste em sucessivas integrações:

- Integração temporal como vertente inicial, o bebê continua a existir.

- Integração no espaço, segunda vertente, o tempo passa e o bebê pode unir-se ao colo, ao berço, ao quarto. Na verdade, e embora Winnicott se utilize da palavra espaço, o seu espaço tem, inicialmente, um sentido de lugar, quando o bebê está fundido com a mãe-ambiente.

- Integração do ego no corpo, personalização. Enquanto para Freud o ego psíquico é uma projeção do ego corpóreo, para Winnicott ele é parte da pessoa, não está no corpo da pessoa. A origem da constituição do ego tem uma base física, o corpo, mas não é biológica e depende das duas integrações anteriores. Neste estágio o bebê começa a construir a pele psíquica e esta não necessariamente coincide com a pele corpórea. Pode estar muito aquém do limite do corpo, ou além, por exemplo, na roupa, ou no quarto. A própria idéia de corpo está em questão. Há casos em que, se as integrações anteriores não aconteceram, nem haverá corpo. Se o bebê sente o ambiente confiável, ele inicia a criação de seu corpo, elabora-o imaginativamente, através da sua interpretação dos percursos dos alimentos, dos excrementos, e assim por diante. A imagem e as funções que cada indivíduo cria como corpo, também não necessariamente pode coincidir com as funções fisiológicas realizadas por ele.

- Finalmente, a capacidade de relacionar-se com os objetos vem como última etapa de constituição de si mesmo, porque ao incorporar os cuidados maternos como modo de existir e depois de criar seu próprio corpo, o indivíduo cria uma realidade psíquica interna separada da realidade externa, ou seja, sua própria identidade ${ }^{4}$. Poderíamos dizer que o que é chamado de inconsciente,

4. D.W. Winnicott. O ambiente e os processos de maturação. Porto Alegre, Artes Médicas, 1990, p. 211. "Quais são as principais coisas que ocorrem no crescimento emocional do lactante nas semanas e meses mais precoces (e que são consolidadas em idades posteriores?). Três delas são: 


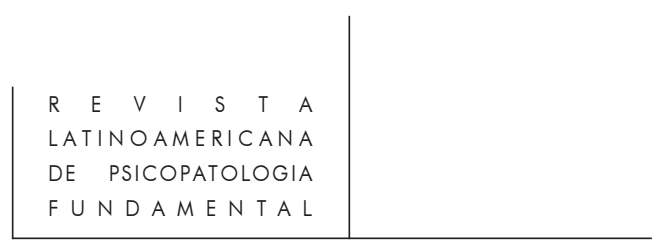

como algo interno, só vai existir quando existir ego. O ambiente não é nem interno e nem externo, porque estas são categorias que se formam depois da constituição do indivíduo como pessoa. A noção de espaço, que tradicionalmente tem fundamentado todas as tratadísticas de arquitetura, implica em algum tipo de distância (mensurável como as medidas ou não como os sonhos, os mitos ou o vazio que constitui as relações com os objetos estruturados como linguagem verbal). O estado de fusão mãe-bebê não é espacial. Trata-se da experiência de um lugar.

Ao longo da existência, o indivíduo amadurece desenvolvendo a capacidade de estar só, como capacidade de ser realmente o que se é, apenas acompanhado por outros seres humanos. Se a existência de um indivíduo é seu modo de ser, este poderá ser compreendido, à medida que nos colocamos nos lugares em que ele esteve ou está, mas, jamais, explicado. O que um indivíduo é mais próprio nunca pode será comunicado, sob ameaça de aniquilamento do ego. Entendo que a casa é o lugar onde a mais profunda intimidade fica protegida. Quando se está só, há um desocultamento do ser na presença de outrem. A casa revela o modo de ser de um indivíduo no mundo, protegido pela ilusão de presença materializada pela arquitetura da casa. A casa diz, não dizendo, daquele que nela habita ${ }^{5}$.

Integração/Personalização/Relações Objetais. O ego do lactante é muito forte, mas apenas por causa do apoio dado ao ego por uma mãe suficientemente boa, que é capaz de jogar todo o seu ser para se adaptar às necessidades de seu bebê, gradativamente recuando desta posição à medida que o lactante precisa que ela se adapte cada vez menos. Sem este apoio ao ego, o ego do lactante está não-estabelecido, fraco, facilmente perturbado e incapaz de crescer de acordo com as linhas do processo de maturação".

5. Gostaria de lembrar um dos relatos de caso de Winnicott, o caso do menino Bob. Após um ano do término do tratamento, o menino Bob procura Winnicott para apresentá-lo ao irmão Winnicott os convida a entrar em sua casa, mostrando-a aos meninos. Normalmente isto poderia indicar a cura do menino, agora capaz de transferir a dependência em relação ao analista para as coisas ou a capacidade dele relacionar-se com os objetos. Mas me pergunto porque Bob escolheu a casa de Winnicott e não qualquer outro objeto? A casa de Winnicott é também o modo de ser de Winnicott porque abraça espacialmente as formas espaciais que revelam o sentido e o ordenamento que ele estabelece para o mundo. Essa casa é um ambiente real que envolve e pode ser percorrido, tem espessura. Minha hipótese é de que se pode fazer uma aproximação entre a estrutura do funcionamento corpóreo organizada pela elaboração imaginativa necessária para um indivíduo começar a existir e a estrutura de organização espacial dos lugares que este mesmo indivíduo ocupa no mundo. Mesmo em idades posteriores, nunca um ambiente torna-se totalmente um objeto. Parcialmente, ele sempre será um objeto-subjetivo. A discussão sobre a "crise do objeto" também está presente em algumas tendências de arquitetura contemporânea e nas artes em geral. 


\section{Ambiente}

A partir do conceito de objeto-subjetivo em Winnicott, pretendo introduzir o tema da casa e a idéia de que há uma transformação do que ela é para o indivíduo durante as suas várias idades, ou, de outro modo, que a modificação dos nossos modos de morar são também a transformação do lugar em que vivemos no mundo num intervalo de tempo.

Certa de que posso correr alguns riscos epistemológicos, gostaria de fazer uma aproximação entre a psicanálise winnicottiana e a arquitetura. As duas tratam do lugar onde vivemos. Do habitat. Vejo a contribuição de Winnicott para a arquitetura no sentido de revelar aos arquitetos que a matéria profunda que move a construção de um edifício não são, simplesmente, as pedras ou as relações formais matemáticas e geométricas, mas um momento na vida do indivíduo em que se vai construir o "onde você é você": a casa.

A arquitetura da casa encontra-se entre duas formas temporais de habitar: a casa como colo da mãe $e$ a casa como abrigo na poesia. Ela encerra um paradoxo: ao mesmo tempo que deve ser concreta e presente deve desterritorializar o indivíduo pela sua qualidade poética (construir a morada na falha ambiental). Esta arquitetura de que falo, não é aquela arquitetura enquanto disciplina forte e arquitetônica. No entanto, sempre se morou em algum lugar, embora, saber morar, seja quase uma arte, tal qual a arte de viver ${ }^{6}$.

A construção de sua casa própria é um acontecimento na vida de qualquer ser humano. Nesse momento a casa não é um objeto. Há uma retorno a um estágio mais anterior no desenvolvimento do indivíduo, em que a dependência do ego da mãe, na forma de seus cuidados e modo de existir, fez com que o bebê fosse apresentado às relações objetais.

Winnicott aponta que o ser humano não pode existir sem um habitat. Para o bebê, o ambiente é a mãe, a mãe-ambiente. É a mãe quem dá o primeiro habitat, constituído pelos cuidados maternos holding e handing.

Holding é sustentar, dar braços, ter nos braços, segurar para o bebê não se sentir fragmentar-se. Este segurar o bebê incluiria amparar a cabeça e os pés com os braços, sustentando o corpo e envolvendo-o para que nada sobre. É também dar um solo e abrigo. A casa deve abrigar, deve ser antes de tudo presente; num nível mais primário deve dar a sensação de proteção para ser

6. Aqui estou me referindo à proposta derradeira de Foucault: fazer da vida uma obra de arte, a proposta de uma "estética existencial" quando saber morar se tornaria, também, uma forma de arte. Para cada um desenvolver seu estilo de vida, deve encontrar um lugar. Os últimos escritos de Foucault deslocam a problemática do biopoder para a constituição de uma estética de si, tal como encontramos nos cursos que ele dedicou à Subjetividade e verdade (1980-81), Hermenêutica do sujeito (1982) e O governo de si e do outros (1983). 


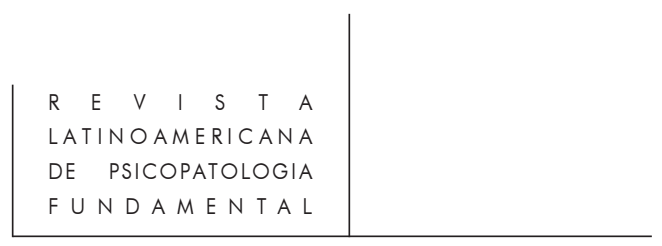

confiável, contra o frio ou calor demasiado, estruturalmente segura, impermeável. $\mathrm{O}$ holding permite a integração espaço-temporal.

Handing seria a preocupação materna com o corpo do bebê, com a higiene, a alimentação, o vestuário. Se fizermos uma transposição para a arquitetura, o handing se traduziria pela temperatura, luminosidade, textura dos materiais que envolvem o indivíduo num espaço, formando uma atmosfera ou um ambiente. Também o abastecimento e infraestrutura que garantem a habitabilidade. O handing permite a personalização ou a instalação do ego como parte do corpo.

O terceiro aspecto da preocupação materna primária é a apresentação dos objetos. A mãe introduz ou inicia o indivíduo nas relações objetais, apresenta o bebê ao mundo. A mãe-ambiente faz o bebê sentir-se capaz de criar objetos. $\mathrm{O}$ bebê, no início, não possui corpo, portanto, não possui ego. O bebê se utiliza do ego forte da mãe para sustentar-se. A mãe não é um objeto externo e nem interno ao bebê, não há corpo ainda, nem interioridade ou exterioridade. Mãe e bebê estão fundidos. A mãe-ambiente é um objeto subjetivamente percebido (objeto-subjetivo). Para Winnicott, se a mãe é suficientemente boa, ela vai ao encontro das expectativas do bebê. A expectativa não consiste ainda em necessidade, não está formulada em algum objeto específico e também não pode ser confundida com desejo ou instintos sexuais. Estes só aparecerão se o bebê tiver sucesso na sua instalação no mundo, que significa estruturar-se a si mesmo. Deste modo, o bebê cria a ilusão de que é ele próprio que cria os objetos. É nesta confiança no ambiente que o bebê adquire confiança em si mesmo e constrói um self verdadeiro pela experiência de si mesmo como experiência de onipotência. A mãe, assim fazendo, apresenta o mundo ao bebê. Ao final do processo há uma separação entre aquilo que é o bebê, o si mesmo e o mundo como território dos símbolos.

Acredito que pode haver uma contribuição da arquitetura ao campo da psicanálise, à medida que a primeira pode fornecer modos de leitura para a compreensão dos estudos de casos em que a questão espacial esteja por demais em evidência. Como veremos mais adiante, preocupações excessivas com a provisão ambiental, da qual o espaço constitui-se um dos aspectos, pode denunciar que o ambiente não foi incorporado pelo bebê em seus primeiros dias. O ambiente confiável produz uma sensação de segurança no bebê, de modo que ele nem o perceberia. O ambiente favorável é um fundo esquecido. Esta experiência poderia encontrar, na arte, um equivalente naquilo que Walter Benjamin chamou de "percepção desatenta".

É necessário lembrar que a capacidade de maturação de um indivíduo, apresentada por Winnicott, não se dá sozinha. "O êxito neste campo do desenvolvimento está intimamente ligado à capacidade da pessoa de se sentir real; isto, contudo, tem de combinar com a idéia de se sentir real no mundo e sentir 
o mundo real" " . Ela exige uma adaptação ambiental. Isto quer dizer que se o arquiteto é aquele responsável pelo ambiente urbano, deve adaptar-se ao desenvolvimento emocional e emancipatório que o cliente, seja um indivíduo ou um determinado grupo social, estiver demonstrando. Para Winnicott, a maioria das pessoas normais só pode fazer uma aproximação da qualidade de sentimento de uma realidade baseada unicamente na relação com os objetos subjetivos (como no mundo de um esquizofrênico) pela vida cultural.

\section{A casa na cidade}

Escrever sobre a casa me parece o contraponto necessário para compreender uma situação de transitoriedade que as metrópoles enfrentam. Pretendo, aqui, apresentar a relação entre indivíduo, a casa-ambiente e a cidade. A casa na cidade, talvez, seja o meu modo de dizer do ser-aí-no-mundo.

Gostaria de introduzir o motivo da casa acompanhada da transcrição de uma nota de Loparic (1995) encontrada em Ética e finitude ${ }^{8}$ :

O morar heideggeriano é o modo de ser do homem irredutível à intencionalidade da consciência, tanto representacional como apetitiva. Por conseguinte, o morar enquanto projetar e tomar-chão no mundo-projeto, em Ser e tempo, ou enquanto mundo-quadrindade, do segundo Heidegger, não pode mais ser pensado como uma relação do tipo sujeito-objeto. O suporte desse morar não é sujeito ("sub-jacente") consciente e o mundo habitado não é objeto ("ob-jacente") de representações ou desejos. Com a morte da subjetividade transcendental kantiana morreu também a objetalidade. Uma análoga "destruição" das relações objetais está ocorrendo na teoria das doenças psíquicas. A psicanálise, desde Freud até Lacan, concentrava-se sobre o desejo, interpretado a partir do conceito de pulsão objetal, e seguia, tanto na teoria como na cura, os destinos dos seus vínculos objetais. Teorias mais recentes, como a de Winnicott, põem em evidência modos de existir humanos em relação à mãe-ambiente ("mãe-jacência"), isto é, modos mais fundamentais e anteriores à formação do solo pulsional. Consequientemente, essas teorias remetem as psicopatologias profundas aos problemas iniciais de inserção no ambiente, e não mais a perdas ou conflitos objetais. Esse paralelismo notável entre desenvolvimentos dominantes na filosofia do século e as alternativas inovadoras na teoria psicopatológica ainda não recebeu, parece-me, a devida atenção nos dois campos.

7. D.W. Winnicott. "Os doentes mentais na prática clínica" (1963), in $O$ ambiente e os processos de maturação. Op. cit., p. 202.

8. Z. Loparic. Ética e finitude. São Paulo, Educ, 1995, p. 79. 


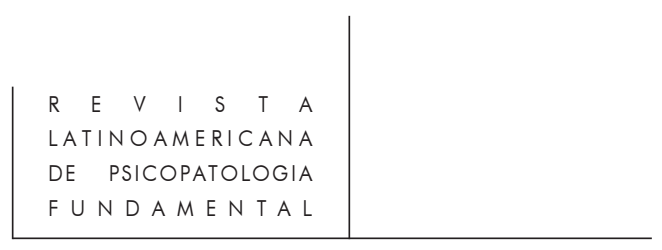

Para falar da casa na cidade é preciso retomar o problema da impossibilidade da constituição de lugares permanentes na metrópole. Antigamente os lugares eram definidos por marcos, monumentos ou elementos físicos de referência e orientação. Nosso lugar da infância, os quartos, os quintais, os porões, os sótãos, os campanários, as torres, os bosques, as praças eram facilmente identificáveis. Hoje a cidade tornou-se um conjunto de artérias viárias e de informação e impedem que nos fixemos por mais de alguns segundos diante de qualquer edifício ou imagem. Também estão muito adensadas e homogêneas. A casa, me parece, é o único reduto capaz de oferecer abrigo e lugar de referência. Mas a contemporaneidade técnica, tutelada pelo paradigma da informação eletrônica, também impõe que se desmaterialize a realidade da casa concreta e propõe que habitemos numa imagem de casa.

Desterritorializa, forçosamente, a presença da casa. Isto se constitui num problema psicanalítico, uma vez que nem todos os indivíduos atingiram a maturidade emocional que permite dispensar a dependência do ambiente real e suportar sozinho sua ausência, à medida que, prematuramente, se percebe que a casa não passa de uma ilusão. Não são todos os indivíduos que têm condições de habitar na re-apresentação da casa inaugurada como palavra escrita pela poética das imagens ${ }^{9}$. O destino do ser que encontra, finalmente, abrigo na linguagem, é o caminho já apontado por Heidegger posterior a Ser e tempo.

Winnicott me ajuda a perguntar de outro modo: um bebê pode existir cuidado por uma imagem materna ou por uma mãe virtual? Os cuidados primários podem ser realizados por qualquer pessoa que se coloque no lugar da mãe. Mas esta pessoa é real, e também existe. O bebê conseguirá se integrar, se incorporar o modo como foi cuidado, sentindo-se ele próprio real.

$\mathrm{Na}$ verdade, o bebê cria uma ilusão de que é real pela experiência de onipotência, ou sucumbirá à angústia impensada experienciada de onde veio, a não-existência. O ser humano que edifica a casa precisa de outro ser humano, o arquiteto ou o construtor, que devem tratá-la não como coisa, mas como parte

9. Estou me referindo à possibilidade de considerar arquitetura uma linguagem. Esta dedução de que a arquitetura é uma linguagem não é tão óbvia. A questão se demonstra muito complexa, e são diversas as formas como as correntes e escolas tratam de modo particular problemas como: se a arquitetura é um "sistema", se obedecem às leis próprias da comunicação, se são constituídas de forma e conteúdo etc. No entanto, estes aspectos se referem preferencialmente aos estudos específicos de semiótica da arquitetura, ou, de outro modo, à capacidade da arquitetura se constituir numa linguagem verbal. Em contrapartida, a minha preocupação em relacionar a arquitetura e comunicação se verificará através da exploração das tendências atuais de pesquisa, como, por exemplo, a noção de textualidade ou arquitetura como linguagem não-verbal e arquitetura como performance, arquitetura-atuação e os estudos sobre as superfícies como peles corpóreas. 
do próprio indivíduo. A casa-ambiente não é uma casa-coisa. Acho que neste ponto a arquitetura encontra a psicanálise.

A imagem da casa pode ser, para um adulto maduro, a necessária ilusão de se ser real, uma vez que no estágio de tenra infância, existiu uma identificação entre si mesmo e a mãe-ambiente como objeto-subjetivo. Nos indivíduos que se sentem angustiados, quando a materialidade ou realidade do ambiente é abalada, percebo um nível de imaturidade referente ao estágio pouco anterior ao início das relações objetais; dificuldade com a personalização revelam falhas ambientais no cuidado corpóreo com o bebê ${ }^{10}$. São aqueles cujos limites do ego ou a membrana psíquica não coincide com a pele corpórea, mas estendem-se para o quarto e a casa. Nestes casos, transformar, destruir, ou simplesmente tocar na casa significa destruir ou agredir o próprio ser humano porque o quarto ou a casa ainda não é um objeto externo. Esta situação da casa pode ser metaforizada em algo como um casulo, quando a larva ainda não se transformou numa borboleta; o corpo é o casulo que é, ao mesmo tempo, os outros dois estados. Só após o processo de morfogênese completado é que há a separação do casulo do corpo.

O que aconteceu com a organização da forma arquitetônica das cidades? Arquitetura da megalópole Aos olhos da estruturação tradicional dos espaços, as novas cidades são desestruturadas. Mas também pode ser visto como um estado ainda não estruturado de um novo tipo de organização. A cidade tem de dar lugar a outras maneiras de elaborar modos de organização das coisas e funcionamento do mundo, ao mesmo tempo que se criam novas estruturas de espaços. A isso aliase a possibilidade de descentralização dessas organizações, gerada pelas tecnologias que permitem operar à distância. Um problema que os arquitetos têm se dedicado recentemente consiste no destino das cidades com a ausência de contato real (fenômeno iniciado pelo uso massivo da Internet como forma de comunicação e relação pessoal à distância), e as consequiências psicossociais da perda da esfera pública, levando a degradações do ambiente urbano nunca antes imaginadas, na forma de todos os tipos de violência, delinqüência, vandalismo, guetificações e deterioração de bairros inteiros.

Anotações de arquiteto. Por exemplo: até muito pouco tempo, estudar na escola/brincar numa pracinha/comer num restaurante ou na cozinha/morar em casa. Hoje: brincar sobre uma mesa no computador/comer em qualquer parte, desde trabalhando até pedir uma pizza num congestionamento de veículos que

10. Cf. D.W. Winnicott. "Os doentes mentais na prática clínica”, in op. cit., p. 201. 


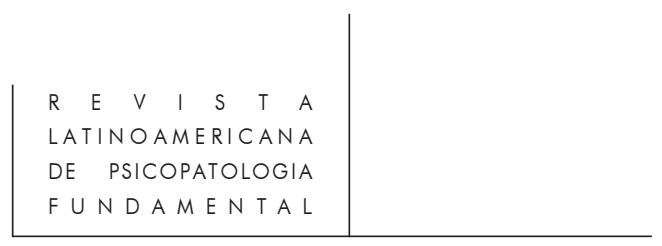

dure mais de uma hora/morar num transporte ou sempre provisoriamente num hotel-residência /trabalhar em casa ou em qualquer parte desde que devidamente munidos de celulares, modens e números de todos os serviços à domicílio. Não são mais as funções que definem as formas, e nem estas, independentes, dão conta da mobilidade do mundo contemporâneo, porque estão ainda comprometidos com antigos modelos e estruturas rígidas.

Se havia uma forma que estava relacionada à escola, à igreja, à casa, e eram estes os locais onde se realizavam estas atividades, as formas informavam externamente aquilo que acontecia no interior das edificações. No entanto, quando se vai pela cidade, e agora se olha para um edifício contemporâneo, não se pode dizer o que ele contém, mesmo porque as pessoas não encontraram uma forma de comunicar a re-organização que está ainda em processamento.

A arquitetura pode revelar um ordenamento não-estrutrado do espaço. Pela minha observação, quando vários arquitetos conseguem realizar desconstruções em arquiteturas, quando alguém paga para fazer isso, deve-se ter como referência que há uma "fase de loucura" coletiva, disseminada no ambiente urbano, que vai além da loucura individual patológica de um arquiteto ou de um cliente.

Hoje, parece até que a expressão "fase de loucura" já foi absorvida e vulgarizada pela sociedade, e é possível encontrá-la em qualquer "Manual de Gestão da Qualidade Total", por exemplo. De modo bem abrangente, a sociedade na era da comunicação generalizada será aquela em que os indivíduos devem deixar de ser dependentes (de seus vínculos empregatícios, de suas famílias ou do Estado), para serem totalmente responsáveis por si próprios, e a fase de loucura consiste justamente nessa transitoriedade. Nas empresas deixarão de existir empregados, mas haverão trabalhadores que gerenciarão sua empregatibilidade, os serviços públicos serão privatizados. Estou dizendo tudo isso para chegar ao tema que interessa a qualquer indivíduo - a cidade.

A cidade do século XIX era a metrópole, como disse Benjamin. A cidade do século XX é a megalópole, e ela exporá e provocará o indivíduo. É interessante observar que Umberto Eco, ao se referir à obra de Lacan demonstra que seu maior mérito teria sido o de nos mostrar que a angústia contemporânea é a angústia de nos sentirmos eliminados pelo sistema. De outro modo, pode-se dizer que é a angústia diante da provocação caracterizada pelo processo de emancipação à força, acontecendo antes que os indivíduos estejam realmente prontos como seres adultos. Não adianta querermos voltar a viver em comunidades, onde as relações são mais controláveis. O fenômeno "condomínio fechado" nada mais é do que um sintoma do generalizado estado de insegurança que as pessoas vivem hoje, falta de confiança no ambiente e em si próprios.

Este aspecto atrai minha atenção, porque coloca mais uma responsabilidade para os indivíduos: a criação do espaço depende cada vez mais de cada um, do 
seu modo de ser, de como cada um organiza suas atividades no mundo e o seu tempo. O desenho da cidade se faz pelo gesto pessoal como experiência corpórea individual. O que se vê? Uma cidade caótica. Talvez porque todos esperem que o outro tome alguma iniciativa num processo que é intransferível. Se a cidade é construída pelo movimento, sua organização dependerá muito do estado de integração do indivíduo no espaço e no tempo.

É inevitável a sensação de desorientação. A metrópole expõe o indivíduo à medida que o "provoca" para movimentar-se. A cidade-ambiente falha fazendo o ser imaturo repetir a experiência angustiante (angústias impensáveis por Winnicott) da ameaça de deixar de ser. Ameaças de não-ser ${ }^{11}$ exigidas pela vida na cidade que determina a realidade como performance.

Winnicott apresenta algumas poucas variações da angústia impensável que tentarei relacionar não à psicopatologia, mas a algumas experiências espaciais reveladas pela megalópole:

1. Desintegração - cisão, fragmentação. Edificar fortalezas. Proteger com muros e grades da invasão do mundo externo. Condomínios fechados são bairros autistas.

2. Cair para sempre - Não ter um chão, vertigem de elevadores, passarelas, escadas rolantes, transportes aéreos e marítimos, edifícios altos, pisos transparentes. As crianças brincam com essas sensações nos parques de diversão, retomando a experiência originária com ação da gravidade. O cuidado materno intra-uterino se faz em todas as direções. Após o nascimento, e durante toda a vida, o cuidado se manifestará pela presença de um solo cuja ação se faz sentir somente de baixo para cima. Alterações na estabilidade espacial podem aflorar sentidos de descuido e insegurança, desterritorializando um indivíduo em proporções que ultrapassam a sua capacidade de reconstituição dos lugares que ocupa no mundo.

3. Não ter conexão alguma com o corpo - Não constituir-se num corpo unitário. Redes de infraestrutura deficitárias. Pontes, viadutos, túneis procuram ligar regiões descontínuas espacialmente. Também a perda da identidade de regiões

11. E. Subirats. "Os maus dias passarão", in Vanguarda, mídia, metrópoles, São Paulo, Nobel, 1993, pp. 33-34. A cidade é o lugar de indivíduos maduros. Reproduzo, aqui, pelas palavras de Eduardo Subirats a descrição do quadro da angústia existencial que afeta um ego frágil de indivíduo imaturo morador da metrópole: "Não-ser como sujeito autônomo responsável. Não-ser como existente numa comunidade solidária de indivíduos. Não-ser como portadores de uma civilização capaz de integrar em seu seio culturas, formas de vida, identidades diferenciadas e cheias de sentido em meio de um diálogo real. Não-ser como indivíduo biológico que geme, luta e estremece num posterior esforço ao mesmo tempo por sua preservação como espécie e por sua integridade perante agressões genéticas, informáticas ou ecológicas que o progresso, sob sua forma agressiva, lhe aflige hoje." (...) "Nossa civilização industrial vive hoje o dilema permanente entre a agressividade que a fundamenta e a angústia que a perpetua". 


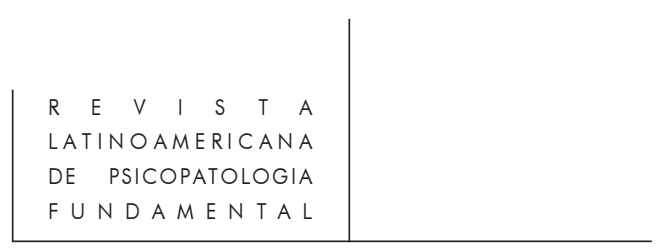

urbanas permite pensar numa falta de corpo ou "rosto" para certos espaços, em termos de um contorno. A identidade, nos indivíduos, se daria com uma aproximação da pele psíquica aos limites do corpo, ou da localização do ego no corpo.

4. Carecer de orientação - Estar fora do lugar. Perdido ou atrasado. Agorafobias, deixar-se vagar na multidão. Nômades, andarilhos. Para se orientar têm que dominar uma escala supra-humana. Já não basta caminhar com os próprios pés. Nova York é próxima de São Paulo, por exemplo. Também é possível perder-se por entre as vitrines espelhadas das galerias labirínticas de um shopping, uma das obras arquitetônicas mais evidentes de construção de um falso lugar.

\section{Casa do nômade}

A casa do nômade é o labirinto. "O labirinto é a pátria de quem hesita. O itinerário de quem teme chegar ao fim desenhará facilmente o labirinto." ${ }^{12}$ Chegar ao fim, não necessariamente significa achar uma saída. Entendo que "chegar ao fim" é encontrar-se a si próprio. Espantar-se ao ficar frente a frente ao que se é. O nômade é aquele que se perde diante de todas as possibilidades de ele ser.

A angústia pode se dar não apenas diante da situação de se ter que escolher apenas um caminho, diante da tensão de ser castrado. Mas a angústia pode vir diante de uma visão de si próprio como infinitas possibilidades. O nômade é um ser que não encontrou o lugar onde pode ser ele próprio. Ele não é um viajante, uma vez que este é capaz de fazer de qualquer lugar seu abrigo. O nômade vive à deriva. Não à deriva dos desejos e pulsões como quer fazer crer algumas tendências no campo da psicanálise ${ }^{13}$, na imagem que Loparic faz de um vagante na cama materna. A psicanálise de Winnicott trata do problema em termos de instalação no colo materno.

É interessante observar que existem alguns tipos diferentes de labirintos, conforme a classificação de Umberto Eco ${ }^{14}$ :

O primeiro tipo é o do labirinto clássico ou unicursal. Tem apenas um curso que, geralmente, conduz a um centro e volta-se pelo mesmo caminho. No centro

12. Olgária C.F. Mattos. "Espaço e tempo: a cidade e a história viajante", Rev. Caramelo 7, 1994, pp. 187-196.

13. A idéia de deslocamentos sucessivos de desejo construindo uma estrutura ausente de objetos como caminho amplamente explorado por Lacan, mantém a discussão ainda dentro de um universo dialético da objetalidade e parece-me conduzir às especulações filosófico-psicanalíticas apontadas por Deleuze e Guattari em suas cartografias ou topografias de desejos.

14. Umberto Eco. "L'antiporfirio", in G. Vattimo e P.A. Rovatti (coord.). Il piensero debole. Milão, Feltrinelli, 1995, pp. 76-79. 
está o Minotauro, como conta a lenda, um estranho ao labirinto. Na verdade, não é possível perder-se, mas quem produz a sensação de desorientação é a presença do fio de Ariadne que constrói o labirinto.

O segundo tipo é o labirinto maneirístico, Irrweg (desvio, caminho falso). Ele propõe a escolha de um único caminho em meio a outros sem saída. Tem um esquema arbóreo. Aqui o Minotauro já faz parte, é o próprio visitante, e não é algo estranho, mas aqueles que se perderam e não encontraram a saída fazem o Minotauro. O fio de Ariadne é importante, porque o visitante é capaz de se auto-enganar ao procurar a saída. Angústia diante de uma passagem estreita e pânico diante da possibilidade de não encontrar nenhuma saída.

O terceiro tipo, ao qual gostaria de relacionar as psicopatologias contemporâneas, por exemplo a esquizofrenia, é um labirinto da reta, rizoma, cuja ponta de segmento pode conectar-se com qualquer outra ponta. A diferença deste labirinto em relação aos outros, é que não há saída ou entrada, porque não existe espaço interno ou externo. Não é possível se fazer uma idéia de sua totalidade, apenas imaginá-la a partir das localidades. A imagem reguladora deste labirinto será hipotética e a cada mudança de direção neste emaranhado que forma o labirinto tridimensional poliédrico, e sem forma, deverá ser revisada a sua imagem do todo. Ele pode ser finito ou infinito (expandir-se). A angústia viria da impossibilidade de traçar um caminho, já que a escolha de qualquer reta é possível. Não há início ou fim e a qualquer momento é possível percorrer uma reta que já havia sido percorrida, sendo que o percurso será sempre inédito. Este labirinto segue de uma tradição enciclopédica.

Mas o enigma do labirinto não está no espaço. É o tempo. O tempo do labirinto é a eternidade. Assim como em Borges, a "cidade dos imortais" tem o desenho do labirinto. Aquele que suporta a finitude e a fragilidade da existência criará, logo, seu próprio percurso narrativo, a partir das localidades, imaginando uma configuração global para o mundo, sem se preocupar demasiadamente com o que passou ou com aquilo que virá acontecer, e ao fim da jornada haverá vivido e terá uma história para contar.

Anotações de arquiteto: grandes congestionamentos criam um lugar para aqueles que estão em perpétuo deslocamento. Pesquisas sempre revelam o aumento do número de veículos na cidade, a incompetência das empresas de coordenação do tráfego, ausência de obras viárias. Ninguém se pergunta porque em cidades como São Paulo, um motorista passa até um quarto do dia no trânsito. No carro, o indivíduo está só. O trânsito é sempre a desculpa necessária à sociedade para ele ter tempo para si mesmo, para pensar na vida, ouvir música, tomar decisões, preparar diálogos inteiros. Ele se esquece que não tem casa. Um motorista se abriga no desabrigo. 


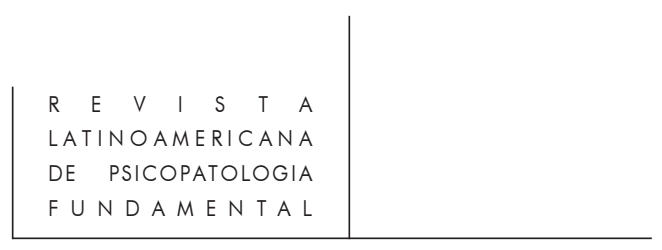

Assim como os motoristas, os turistas, os nômades e andarilhos, os semteto, os sem-terra, os desempregados, os favelados, os que moram em área de risco, formam legiões de pessoas que não encontram um lugar de residência. Os sem-teto e os sem-terra procuram um assentamento. Os que vivem em favelas, a despeito da condição econômica, moram em "sub-habitações", vivem em crônica dependência da doação de um solo, dos serviços urbanos. E quando da ameaça de reinstalação em outros locais ou quando são contemplados por programas de habitação popular, recusam-se ou até mudam de favela para não assumir as responsabilidades urbanas de cidadãos e enfrentar um momento de instalação espacial mais definitiva ${ }^{15}$.

É comum encontrar depoimentos de moradores que reconstruíram a casa em que vivem mais de cinco vezes num período de dez anos, incluindo a reposição de todos os móveis e utensílios, que por motivos diversos foram destruídos. O processo da edificação da casa pode ser contínuo, mas pode significar que a constituição de um si mesmo talvez nunca venha a ser totalmente concluída.

É possível perceber que a cidade-mundo tornou-se um lugar desconfiável. Ao falhar, o ambiente urbano estaria repetindo uma falha de cuidado materno primário capaz de desestruturar o ego fraco de um indivíduo.

Winnicott fala da dificuldade de se formular este conceito pelo fato de haver uma posição intermediária: "a provisão ambiental é boa no início, mas falha depois" ${ }^{16}$. Se a provisão ambiental é suficientemente boa, o bebê se identifica

15. Sobre este aspecto chamou-me a atenção o processo de relocação de algumas populações moradoras em áreas de favelas de São Paulo, ao realizar Relatório de Diretrizes Ambientais em 1997. O programa de verticalização de favelas introduzia novos modos de habitar. Mais do que resolver um problema de fornecer uma moradia a preço acessível, o programa exigia uma fase de moradia temporária acompanhada por sociólogos, psicólogos, arquitetos onde os moradores passariam a criar novos modos de morar, principalmente associado ao cuidado em relação à manutenção do ambiente. Interessante observar que a parcela de população que conseguiu se instalar nas novas moradias, em locais onde o plano assistência de transição foi devidamente implementado, teve sua estrutura familiar reconstruída, requalificou-se para um novo emprego As outras retornaram à mesma situação, incorporando-se em outras favelas. Pode-se falar algo no mesmo sentido sobre as populações que se instalam em áreas de risco (encostas e áreas inundáveis). Como essas áreas são as que sobram, essas famílias chegam muito depois de um processo de urbanização já consolidado, mas são as primeiras a serem atendidas no caso de uma requalificação na cidade. A responsabilidade sobre a vida dos moradores em áreas de risco pertence à esfera pública. Esta situação me faz pensar em estados de ego parcialmente integrados, quando o indivíduo experimentou uma instalação precária, e diante da incerteza na continuidade da existência, o caminho possível é o suicídio, que é, também, uma forma de pedir ajuda. Mesmo nas regiões mais favorecidas economicamente e que estão sujeitas à inundações freqüentes, como por exemplo o centro do Rio de Janeiro ou as áreas das marginais em São Paulo, é evidente o estado de pânico em que vivem os moradores.

16. D.W. Winnicott. "Dependência no cuidado do lactante, no cuidado da criança e na situação psicanalítica" (1963), in O Ambiente e os processos de maturação. Op. cit. 
com o ambiente e, como objeto-subjetivo, o ambiente fornece ao indivíduo uma situação de identificação de si mesmo. Esta é a base para a construção do ego do bebê que, agora integrado, pode suportar as falhas ambientais que permitem a ele experimentar a realidade externa e ser o que ele é. Mas se de início há uma organização do ego, e antes que o processo de integração esteja completo, o indivíduo ainda não criou um ambiente interno, ao que Winnicott chama ficar independente e, então, o ambiente falha, esse indivíduo pode ter distúrbios de caráter ou tornar-se um delinqüente ou ser um suicida. Novamente, quando retomamos o ambiente metropolitano, vemos a falta de confiança entre as pessoas.

A cidade solicita o ser humano no sentido de fazê-lo habitar na experiência de oscilação entre a pertença e o desenraizamento. Viver nas grandes cidades pode ser uma experiência extremamente angustiante, basicamente se na instalação primária tiver ocorrido falhas na confiabilidade do ambiente e se elas tiverem se constituído em ameaça na continuidade de existência de um indivíduo.

\section{O lugar da intimidade na era da comunicação generalizada}

De certo modo, para nós arquitetos, o mundo é o urbano (até o ambiente natural já está todo catalogado e monitorado) e a casa é o sítio de intimidade no mundo. Mas algo acontece quando o mundo urbano invade, através da mídia, o sítio de intimidade, a casa. A arquitetura também pode ser obscena, se se permitir que transformemos a casa em objeto de informação e exposição da interioridade de um indivíduo. $\mathrm{O}$ excesso de exposição permite o surgimento de falsas individualidades como organização de defesa. É o que tem acontecido com o incremento tecnológico que permite a comunicação generalizada do mundo.

Em sua análise acerca da contemporaneidade, Subirats faz uma reflexão sobre a relação entre cultura midiática e a metrópole, no sentido de que a real constituição global do mundo como uma grande obra de arte, ou segundo envoltório cerebral planetário na era da comunicação eletrônica, seria a possibilidade de concretização da Utopia Moderna. Um paradoxo: a possibilidade da total acessibilidade à informação objetiva convivendo com a opacidade comunicativa dos sentidos incorporados pelos diversos seres humanos como forma de sobrevivência. E acrescenta:

Somos herdeiros das promessas históricas das vanguardas. Fazemos parte do niilismo pós-estruturalista. Nossos espaços cotidianos estão definidos pela fragmentação e descontextualização de discursos ambíguos, signos surrealisticamente transvalorizados, simulacros midiáticos; somos desestruturados como sujeitos pela construção midiática de eventos históricos 


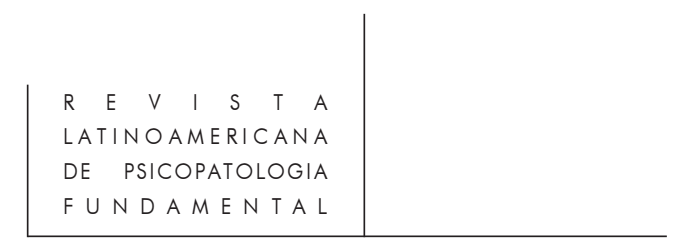

ou pela produção estatal da cultura como espetáculo. E dificilmente podemos nos livrar das doces nostalgias de nossos lares regionais e micro-regionais. ${ }^{17}$

As pessoas desaprenderam a morar.

O indivíduo já não pode se sentir relaxado ou seguro, nem dentro de casa. As estratégias de comunicação de massas estão baseadas em teorias comportamentais, e induz o indivíduo a introjetar classificações e códigos de consumo. O indivíduo, por imitação, adquire uma falsa identidade. Não é capaz de confiar em si mesmo. No lugar de procurar a si mesmo, procura incessantemente por objetos. Está numa linha de fuga sem ponto de convergência. Não tem perspectivas.

$\mathrm{O}$ primeiro arquiteto a indagar-se sobre as conseqüências do vasto processo de mobilização ${ }^{18}$ que desarraigara o mundo moderno desde o início do século, foi Adolf Loos (1870-1932). "Como mostrou Massimo Cacciari, Loos tentou compensar a Entortung (aniquilação do lugar) da metrópolis moderna elaborando o microcosmos de seu Raumplan doméstico e produzindo uma verdadeira concentração de 'lugares', cada um deles com seus adequados revestimentos e alturas de tetos (...)" Continua Cacciari: "O fazer-espaço loosiano sempre tende, no interior, a ceder lugares... A importância do mobiliário, o cuidado pelo material (cuidado no sentido de simpatia profunda) pertencem a esta busca do lugar. Digo... busca precisamente porque não pode haver um lugar puro no destino da Entortung." 19

Outro arquiteto me faz pensar na casa como lugar da intimidade. Louis Kahn (1962) deixou em seus escritos: "a arquitetura cria a sensação de um mundo dentro de outro mundo e atribui esta sensação ao quarto". Por extensão, a rua também seria uma espécie de quarto coletivo que exprime um pacto.

O tema da comunicação é introduzido pela questão da relação com o objeto, pelo objeto-subjetivo. No início da existência, conforme observa Winnicott, o objeto é um fenômeno subjetivo, a mãe-ambiente é humana, mas ao longo do processo maturativo se torna um objeto objetivamente percebido, quando a mãe, também, torna-se objeto. Enquanto o objeto é subjetivo, a relação comunicativa entre mãe-ambiente e bebê não se estabelece em bases verbais, não é explícita. Quando o objeto se torna objetivamente percebido, inicia-se também a consolidação da comunicação verbal.

17. E. Subirats. Op. cit., p. 18.

18. A Mobilmachung de Ernest Jüger corresponde ao processo globalizador da tecnologia moderna, ao qual teriam de se submeter as espécies para sobreviver. Ver Michael E. Zimmerman. Heidegger's Confrontation with Modernity. Bloomington, Indiana University Press, 1990, p. 55.

19. K. Frampton. "Adolf Loos: El arquitecto como maestro de obras", in R. Schezen, Adolf Loos: arquitectura 1903-1932, Barcelona, GG, 1996. 
Para que o objeto seja criado pelo bebê, a mãe deve apresentá-lo. O bebê cria uma ilusão de que cria o objeto (alucinação). Posteriormente, o bebê duvida se encontrou ou criou o objeto (delírio). Quando o ambiente falha, o bebê tende a procurar o objeto. Ao encontrá-lo, o terá como real, se alguma vez o objeto já tiver sido apresentado a ele. A integração do ego confere ao indivíduo a capacidade de se relacionar ao mesmo tempo com o ambiente humano e com as coisas (o que permite esta ambivalência é a capacidade de concernimento da criança).

A exploração do ser humano se dá à medida que ele se transforma também em objeto através da total transparência de significação. Para Winnicott, a pior violação de um ser humano é aquela produzida pela que ultrapassa as defesas que protegem os elementos centrais do self. O ego do ser humano não pode transformar-se em fragmento de informação, o que comprometeria a própria constituição de si mesmo.

Em psicanálise, isto equivaleria a dizer que o excesso de interpretação pode ser desastroso para um ego frágil (imaturo), porque o paciente não estaria pronto para ter experiências com a realidade externa, isto é, ser desiludido. A recusa à comunicação por um indivíduo, não necessariamente representa um estado patológico (neurose), mas estabelece um jogo entre desvelamento e velamento do ser. Winnicott fala de "um eu privado que não se comunica, e ao mesmo tempo querendo se comunicar e ser encontrado. É um sofisticado jogo de esconder em que é uma alegria estar escondido, mas um desastre não ser encontrado" 20 .

Ao descrever este processo, a relação entre ambiente e bebê não se estabelece na base de uma comunicação informativa. Existe uma comunicação silenciosa que se relaciona com os aspectos subjetivos dos objetos e esta experiência é sentida como real. O indivíduo se sente vivo porque se sente real. O que o indivíduo é nunca se saberá totalmente. Somente a linguagem poética é capaz de abrir o horizonte no qual o ser se apresenta, nomeando-o. Mas a linguagem poética não é objetiva.

\section{Da casa-ambiente à casa na linguagem}

A casa revela uma duplicidade: a "construção de uma casa separada do mundo, de uma interioridade, a partir da qual os entes possam ser interpretados, trabalhados, consumidos, acumulados etc. é um primeiro passo inevitável e

20. D.W. Winnicott. "Comunicação e falta de comunicação levando ao estudo de certos opostos", in $O$ ambiente e os processos de maturação. Op. cit., p. 169. 


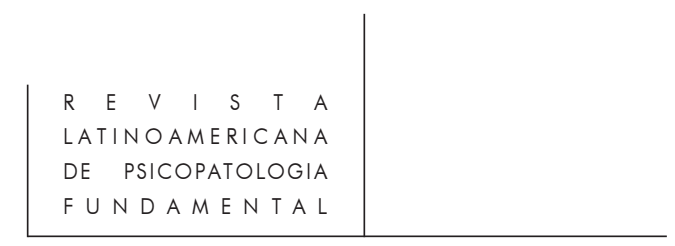

indispensável na constituição do sujeito" ${ }^{21}$. Ao mesmo tempo que ela indica o lugar que abriga, que protege um modo de ser ao qual ela mesma faz parte, é também o espaço que separa o ser si mesmo do mundo, que distancia, e que vai permitir ao ser humano reinaugurar, poeticamente, o mundo.

Então, a casa, enquanto obra arquitetônica, é uma metáfora do modo de ser si mesmo no mundo? Se a resposta é afirmativa, a obra arquitetônica se funda na linguagem. A arquitetura edifica uma linguagem silenciosa entre o indivíduo e o arquiteto como ser humano que possibilita a esse indivíduo criar seu próprio mundo. A arquitetura é a única arte, realmente, capaz de abrigar.

Em Verdade e método, Gadamer (1983) ${ }^{22}$ faz algumas considerações sobre arquitetura:

... arquitetura é pura e simples estruturação do espaço. O espaço é o que abraça tudo que existe espacialmente. A arquitetura abraça por isso as outras formas de representação: todas as obras da arte figurativa, as formas ornamentais. (...) a posição de "compreensão" que a arquitetura tem nos contornos de todas as artes implica numa dupla forma de mediação. Enquanto arte do espaço ela é ao mesmo tempo arte que dá forma ao espaço e arte que situa (...) ela atrai para si a atenção do observador, satisfaz o seu gosto, e por outro lado reporta-o também, além de si própria, para aquele mais amplo contexto vital que acompanha.

Prosseguindo sobre o caráter de ornamentalidade da arquitetura, Gadamer vai dizendo que o motivo ornamental sempre aparece repetidamente. Esta repetição faz com que eles passem despercebidos. Mas ao observar o modo como se processa a repetição dos motivos, como repetição igual, monótona, acaba sendo reconhecido como objeto, ao passo que se a repetição não for uniforme, age de modo vivificante como acompanhamento. "Tudo o que é ornamento e que adorna é definido em relação ao que é destinado a ornar, àquilo que o comporta". Ao apresentar esta conceituação, Gadamer estaria rejeitando qualquer consideração de autenticidade da arquitetura, e privilegiando um caráter de obra decorativa e de acompanhamento. Uma arquitetura que não se pretenda "obra de arte autêntica". A arquitetura, enquanto ornamentação, revela quem nela habita.

Encontro na voz de Sócrates imaginado por Paul Valéry (1945) em Eupalinos ou $O$ arquiteto ${ }^{23}$ apreciação semelhante da obra arquitetônica. "Existimos,

21. L.C. Figueiredo. "Maldiney e Fédida: derivações heideggerianas na direção da psicanálise". Boletim de Novidades da Livraria Pulsional, ano VIII, $\mathrm{n}^{\circ} 79$, nov-1995, São Paulo.

22. H.G. Gadamer. Verità e metodo. Milano, Bompiani, 1983. Trad. Régis Duprat.

23. P. Valéry. Eupalinos oи O arquiteto. Rio de Janeiro, Editora 34, 1996, p. 77. "Há duas artes que encerram o homem dentro do homem; ou melhor, que encerram o ser em sua própria obra, e a alma em seus atos e nas produções de seus atos, assim como nosso corpo de outrora achava- 


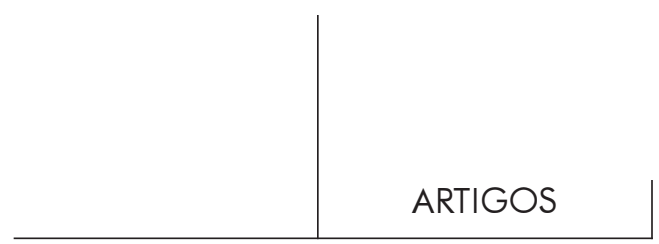

movemo-nos, vivemos na obra de um homem". Isto permite dizer que ao mesmo tempo em que somos envolvidos pelo edifício, despertando em nós um sentimento de pertença, afastamo-nos do nosso mundo real e mergulhamos, "quais peixes dentro d'água" num universo criado pelas proporções e vontades que alguém escolheu. Depois retornamos.

A arquitetura contemporânea vai além, já não é somente o arquiteto. A obra não se impõe como objeto, mas se abre a várias leituras, e haverão tantas obras quantas forem suas interpretações como recriações. A mesma imagem parece sugerir outro arquiteto, Jean Nouvel, autor da Fundação Cartier em Paris. Ele diz: "Luz e matéria tomaram conta das noções de espaço e forma em declínio". E acrescenta que "a transparência é antes de tudo uma maneira de favorecer a interferência do pré-existente e do construído, de integrar todo o ambiente como um componente que é parte integral do espaço criado".

Recorrendo a Rilke de Por que poetas ? $^{24}$, Heidegger se utiliza da metáfora da casa para apresentar o relação da linguagem com o homem. Mas o próprio uso da palavra casa pelo filósofo, quando se refere à linguagem como casa do ser, não revelaria uma experiência concreta de abrigo mais originária, para que um poeta pudesse metaforizá-la em linguagem, reedificando-a ao nomeá-la?

Desta experiência originária de instalação no mundo, a psicanálise de Winnicott pode dar conta. No início a casa é física, mas humana. O colo da mãe, além dos cuidados primários. Conforme o indivíduo amadurece, ou constrói um self verdadeiro, ele pode iniciar-se no poder-morrer, desmaterializando e desterritorializando a sua casa no mundo. Ao incorporar a possibilidade de não mais estar-aí-no-mundo (integração desintegradora), o indivíduo vai encontrar sua derradeira morada naquilo que Heidegger chamará de Quadratura ou Quadrindade. Edificar no mundo-quadrindade ${ }^{25}$ é morar entre o céu e a terra, entre mortais e divinos. "A linguagem nos é dada para que possamos edificar por meio das palavras".

\section{A casa como espaço potencial}

Gadamer, ao referir-se ao caráter ornamental e de fundo da arquitetura, indica que o desenho de seu espaço só pode ser realizado pela experiência vivida

se todo contido nas criações de seu olho, limitado ao ângulo de sua visão. Por duas artes, é o homem de dois modos envolvidos por leis e vontades interiores, figuradas em uma matéria ou outra, a pedra ou o ar. (...) Mas a Música e a Arquitetura fazem-nos pensar em algo totalmente diverso delas próprias; acham-se em meio do mundo, quais monumentos de outro mundo".

24. Utilizo-me do trecho de Holswege transcrito por Benedito Nunes in B. Nunes, Passagem para o poético, São Paulo, Ática, 1986, p. 273.

25. Utilizo-me da tradução de Loparic in Z. Loparic, Ética e finitude, op. cit., p. 76. 


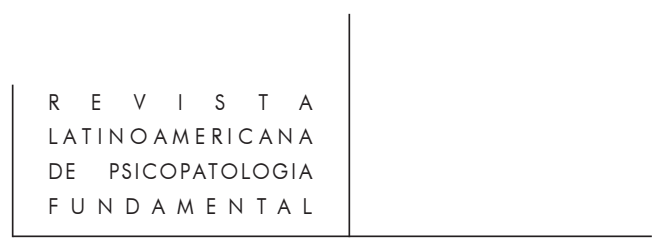

de cada indivíduo. O ornamento não é algo aderido à estruturação do espaço, mas é o próprio redobramento da estrutura como elaboração imaginativa capaz de criar lugares, transformando a matéria. Deste modo, a arquitetura é obra de acompanhamento e decorativa. As demais artes figurativas e plásticas não podem ser decorativas, pois possuem um círculo de significação mais fechado em si mesmas. Mas a arquitetura, oferecendo-se como ornamento, não impõe-se por ter um conteúdo objetivo. "Pode-se dizer, portanto, do ornamento, que pertence à representação; mas a representação é um fato ontológico, é repraesentatio" 26 .

A casa é o espaço no qual o indivíduo encontra o lugar que lhe foi deixado para seu modo de ser no mundo, sendo que este espaço é, também, parte essencial do ser humano. A arquitetura tem tanto a capacidade de aproximar e afastar como espacializar. Em Building, Dwelling and Thinking (1954), Heidegger escreve:

O que a palavra Raum, Rum - espaço - designa vem indicado por seu antigo significado. Raum significa um lugar desocupado ou disponível para assentamento e alojamento. Um espaço é algo para o que se fez lugar, algo que está desocupado e esvaziado, dentro de limites - peras em grego. Os limites não são algo que encerram a passagem, senão, como reconheceram os gregos, aquilo no que algo inicia sua presença. Por isto, o conceito de horismos, quer dizer, o horizonte, o limite. Espaço é, em essência, aquilo para o que foi feito lugar, aquilo para o que se deixa dentro dos limites. Aquilo para o qual se deixa espaço sempre se dá por outorgado e, portanto se reúne, em virtude de uma situação, quer dizer, por uma coisa como a que pode ser o poente. Por conseguinte, os espaços recebem seu ser das situações e não do "espaço" 27.

São, justamente, "as situações de desenraizamento profundo das sociedades em relação às condições naturais" que irão produzir um movimento de refluxo, engendrando o cuidar de si e a edificação de novas moradas. "Num primordial sentir-se em casa é que se cria as condições para as experiências de encontro de alteridades" 28 . Cria-se o lugar onde se está ligado e separado do mundo.

26. H.G. Gadamer. Op. cit. Aqui vem se juntar o conceito de performance apresentado por Weinshelmer em sua análise sobre a obra de Gadamer: "A performance não é uma coisa secundária, acidental ou supérflua que se possa distinguir do texto propriamente dito. Este só existe, para começar, quando é representado. A performance faz a peça existir, a representação da peça é a própria peça... Assim, não podemos diferenciar a obra das suas representações, visto que ela só existe nestas, apenas na carne."

27. Tradução pessoal da tradução espanhola.

28. L.C. Figueiredo. "Foucault e Heidegger: a ética e as formas históricas do habitar (e do não habitar)", in Simpósio Foucault e Heidegger. Um pensamento desconcertante, 1995. São Paulo. Boletim de Novidades da Livraria Pulsional, ano VIII, n ${ }^{\circ} 82$, fev-1996, São Paulo, pp. 5-14.. 
E ao desenhar uma casa como lugar de embate entre a realidade interna e a realidade externa do ser humano, o arquiteto é solicitado duplamente. Primeiro, por um status de artista como aquele que "desce ao foco desse mútuo enfrentamento, à unidade da diferença que reúne os contentores no traçado tenso da matéria" 29 . A obra arquitetônica pode fundar um lugar que possibilita ao indivíduo a criação individual do seu próprio sentido de casa. Ele possibilita ao indivíduo aquilo que Winnicott vai chamar de espaço potencial, a edificação de seu próprio espaço de criação. Não há teoria estética que dê conta, explique ou justifique um desenho. A arquitetura enquanto disciplina que tem sido a própria fortaleza da Metafísica, se enfraquece. A casa é obra de arquitetura sem autor. Ela vai se formando, no início é amorfa. Não é um objeto dado, também não existe distância de observação. Segundo, que o arquiteto, para fazer o cliente construir-se a si mesmo, não pode impor vontades ou desejos, ou apresentar formas pré-determinadas como modelos de casa.

Do ponto de vista do indivíduo que está para construir a casa, ela constituise na experiência vivida de abrigo. Para o arquiteto, ele deve dar lugar à existência do indivíduo, colocando-se no lugar do outro que está próximo. O arquiteto deve ser estrangeiro em seu próprio território. Fédida, em $O$ sítio do estrangeiro (1991), nos diz: "Desenhar obra a ser escutada ao mesmo tempo em que aprende a ver".

O compromisso ético do arquiteto restringe-se a acompanhar, silenciosamente presente, aquele que processa sua instalação no mundo adulto. E deve estar, também, preparado para suportar em silêncio as falhas ambientais que darão espaço ao ser no momento apropriado para a separação ambiental. A obra arquitetônica se faz neste território "entre", o espaço potencial. Esta ruptura permite ao indivíduo criar seu próprio espaço, povoado de símbolos e outras formas representativas. Insisto em considerar arquitetura como ambiente, à medida que acolhe as outras formas de representação. Ao mesmo tempo, a casaambiente evita a total separação do ser e do não-ser porque não é um vazio. Ela funda um lugar para ser ocupado pelo brincar e pela experiência cultural. ${ }^{30}$

29. B. Nunes. Op. cit., p. 257.

30. D.W. Winnicott. O brincar e a realidade. Rio de Janeiro, Imago, 1975, p.151. O arquiteto, às vezes, coloca-se no lugar da mãe, repetindo o processo descrito por Winnicott: "A mãe adaptase às necessidades de seu bebê e de seu filho que gradativamente se desenvolve em personalidade e caráter, e essa adaptação concede-lhe certa medida de fidedignidade. A experiência que o bebê tem dessa fidedignidade, durante certo período de tempo, origina nele, e na criança que cresce, um sentimento de confiança. A confiança do bebê na fidedignidade da mãe e, portanto, na de outras pessoas e coisas, torna possível uma separação do não-eu a partir do eu. Ao mesmo tempo, contudo, pode-se dizer que a separação é evitada pelo preenchimento do espaço potencial com o brincar criativo, com o uso de símbolos e com tudo o que acaba de somar a uma vida cultural." 


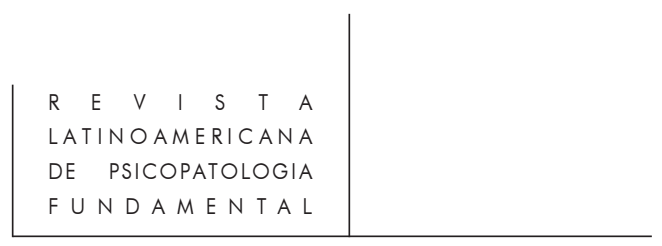

\section{Resumos}

Objetivo establecer una aproximación entre el psicoanálisis de Winnicott y la arquitectura, partiendo de la relación entre ambiente y casa. El abordage winnicottiano del concepto de objeto-sujeto nos permite pensar una fase de fusión entre la madre-bebe que encuentra un paralelismo entre individuo-casa e individuociudad en su fase adulta. Así como el ser humano no puede existitr sin un habitat, como lo señala Winnicott, y que las psicopatologias profundas que se caracterizan por las angustias impensadas seriam decorrentes de fallas en el proceso de instalación del individuo en el mundo. ¿En qué medida la arquitectura puede afectar el existir humano?, desde que es la única de las artes realmente capaz de abrigar, o sea, capaz de constituirse concretamente en un ambiente por su capacidad esencial de envolvimiento, antes de ser tomada como objeto de representaciones y deseos.

Je cherche à établir un rapprochement entre la psychanalyse de Winnicott et l'architecture à partir de la relation entre l'environnement et la maison, et ce parce que l'abordage winnicottienne du concept d'objet-subjectif nous permet de penser à un stade de fusion mère-bébé qui peut être mis en parallèle avec celui d'individumaison et d'individu-ville pendant la phase adulte. L'être humain ne saurait vivre sans habitat, nous dit Winnicott, et les psychopathologies profondes, marquées par des angoisses impensées, peuvent provenir de failles dans le processus d'installation de l'individu dans le monde. Dans quelle mesure, donc, l'architecture, qui est le seul art vraiment capable d'abriter, c'est-à-dire capable de se constituer concrètement en un environnement au moyen de sa capacité essentielle d'enveloppement, avant même d'être appréhendée comme un objet de représentations et de désirs, peut-elle affecter l'existence humaine?

From the relationship between environment and the house, I try to carry out an approximation between Winnicott's psychoanalysis and architecture. In fact, the winnicottian approach of the object-subjective concept allows us to think of a motherbaby fusion stage that can be paralleled to that of individual-home or individualcity in adulthood. Human beings cannot be without a habitat, as Winnicott showed, and deep psychopathology characterised by unthought anguishes might result from a failure in the individual's process of installation in the world. Since it is the only art really able to shelter, i.e., able to concretely constitute itself into an environment through its essential, involving capacity, much before it might even be taken as an object of representations and desires, how deeply may architecture affect human existence? 